\title{
Erratum
}

\section{How diverse is the lichenized fungal family Trypetheliaceae (Ascomycota: Dothideomycetes)? A quantitative prediction of global species richness - ERRATUM}

\author{
André APTROOT, Marcela E. S. CÁCERES, Mark K. JOHNSTON and \\ Robert LÜCKING
}

doi:10.1017/S0024282916000463. Published online for the British Lichen Society by Cambridge University Press, 7 December 2016.

This article was erroneously published to run together with the index. It, and the index, have now been published online as separate articles, with the correct pagination and running heads.

\section{REFERENCE}

Aptroot, A., Cáceres, M.E.S., Johnston, M.K. \& Lücking, R. (2016) How diverse is the lichenized fungal family Trypetheliaceae (Ascomycota: Dothideomycetes)? A quantitative prediction of global species richness. Lichenologist 48 (6): 983-994. 